\title{
SARS-CoV-2 in Human Sewage and River Water from a Remote and Vulnerable Area as a Surveillance Tool in Brazil
}

\author{
Gislaine Fongaro ${ }^{1}$ Paula Rogovski ${ }^{1} \cdot$ Beatriz Pereira Savi ${ }^{1} \cdot$ Rafael Dorighello Cadamuro $^{1}$. \\ Juliana Virgínia Faria Pereira ${ }^{3}$. lago Hashimoto Sant Anna ${ }^{3} \cdot$ Ivan Henrique Rodrigues ${ }^{3}$. \\ Doris Sobral Marques Souza ${ }^{1,2}$. Edgard Gregory Torres Saravia ${ }^{3}$. David Rodríguez-Lázaro ${ }^{4,5}$ (1) \\ Maria Célia da Silva Lanna ${ }^{3}$
}

Received: 7 May 2021 / Accepted: 1 July 2021 / Published online: 8 July 2021

(c) The Author(s), under exclusive licence to Springer Science+Business Media, LLC, part of Springer Nature 2021

\begin{abstract}
In the present study, the severe acute respiratory syndrome coronavirus 2 (SARS-CoV-2) was monitored in environmental samples from rural and vulnerable areas (a presidio, worker accommodation units, and river waters upstream and downstream of a rural community) from Minas Gerais State region, Southern Brazil, in August 2020. The sampling was performed prior to official declaration of the coronavirus disease (COVID-19) cases in those sites. SARS-CoV-2 RNA was detected in the presidio and workers accommodation units $\left(3.0 \times 10^{4}\right.$ virus genome copies $(\mathrm{GC}) / \mathrm{mL}$ and $4.3 \times 10^{4} \mathrm{GC} / \mathrm{mL}$ of sewage, respectively). While SARS-CoV-2 was not detected in the river water upstream of the rural community, SARS-CoV-2 RNA was detected in downstream river waters $\left(1.1 \times 10^{2}\right.$ SARS-CoV-2 GC/mL). The results obtained in this study highlight the utility of SARS-CoV-2 monitoring in wastewater and human sewage as a non-invasive early warning tool to support health surveillance in vulnerable and remote areas, particularly in development countries.
\end{abstract}

Keywords SARS-CoV-2 $\cdot$ COVID-19 $\cdot$ Human sewage $\cdot$ Environmental samples $\cdot$ Sentinel $\cdot$ Epidemiology $\cdot$ Vulnerable areas

Gislaine Fongaro

gislaine.fongaro@ufsc.br

$\bowtie$ David Rodríguez-Lázaro

drlazaro@ubu.es

1 Laboratory of Applied Virology, Department of Microbiology, Immunology and Parasitology, Federal University of Santa Catarina, Florianópolis, SC 88040-900, Brazil

2 Department of Food Science and Technology, Federal University of Santa Catarina, Florianópolis, SC 88034-001, Brazil

3 Institute of Exact and Biological Sciences (ICEB), Federal University of Ouro Preto, Ouro Preto, Brazil

4 Microbiology Division, Faculty of Sciences, University of Burgos, Plaza Misael Bañuelos s/n, 09001 Burgos, Spain

5 Research Centre for Emerging Pathogens and Global Health, University of Burgos, Burgos, Spain

\section{Introduction}

Wastewater and sewage surveillance are being applied for the severe acute respiratory syndrome coronavirus 2 (SARSCoV-2) investigations (WHO, 2020). A number of studies across the world have shown the presence of RNA fragments from SARS-CoV-2 on sewage (Ahmed et al., 2020; La Rosa et al., 2020; Medema et al., 2020; Prado et al., 2020; Wu et al., 2020; Wurtzer et al., 2020). Environmental monitoring can be an advantageous public health tool since SARS-CoV-2 can be detected prior to the appearance of clinical cases on the community demonstrating its value as a non-invasive early warning tool for monitoring the trend of COVID-19 infection (Peccia et al., 2020; Wurtzer et al., 2020), particularly in remote, vulnerable, poor areas where the individual COVID-19 testing is difficult. In this study, we evaluated the presence of SARS-CoV-2 RNA in raw sewage in rural and vulnerable areas in South-eastern Brazil, State of Minas Gerais. The selection of the sampling areas was based on the records of poor implementation of sanitation interventions, extensive iron and aluminium mining 
activity, and local food production from family farming. In addition, the location of a floating population of the miners' quarters stands out, as well as of a regional prison.

\section{The Study}

Raw sewage samples were collected from the entrance to the sink storage box in a presidio area (150 prisoners) ( 5 samples) and in workers accommodation units (100 users) (5 samples) in the Minas Gerais State region, Brazil in August 2020 just with the first COVID-19 wave pick in the region (Fig. 1). River water samples (5 samples per site) were also collected in 3 sites in a low sanitation rural area, one upstream site from a rural community with around 1,500 inhabitants and two downstream sites. The identification of the areas is kept confidential to avoid embarrassment for local residents. Five $2 \mathrm{~L}$-samples were collected in each sampling site. Sewage samples were concentrated using the glycine buffer method and polyethylene glycol precipitation (Lewis \& Metcalf, 1988). River water samples were concentrated using adsorption methods in electronegative membranes (HAWP04700; Merck Millipore Ltda., Sydney, Australia) (Ahmed et al., 2015). A sample process control (SPC), Murine coronavirus (MHV-3), was artificially inoculated in each sample before the concentration process to estimate the efficiency of the concentration and nucleic acid extraction. Viral RNA was extracted from the concentrates using the QIAamp Viral RNA Mini kit (QIAGEN, CA, USA) and SARS-CoV-2 was detected by real-time quantitative RT-PCR (RT-qPCR) using specific oligonucleotides and probes targeting the N1 and N2 regions (CDC, 2020). The MHV-3 $\left(3.0 \times 10^{8}\right.$ genomes copies (GC) $\mathrm{mL}^{-1}$, was detected by RT-qPCR (Besselsen et al., 2003). A commercial SARS-CoV-2 RNA $\left(2.0 \times 10^{6}\right.$ $\mathrm{GC} / \mu \mathrm{L})$ as positive quantitative control was purchased from IDT (Integrated DNA Technologies, Belgium). Standard curves had a dynamic linear range of quantification from $3.0 \times 10^{6}$ to 10 copies/reaction. The slope of the standard curves ranged from -3.245 to -3.334 for MHV-3 and -3.237 to -3.330 for SARS-CoV-2. The amplification efficiencies ranged from 98.7 to 98.6 and the correlation coefficient $\left(\mathrm{r}^{2}\right)$ ranged from 0.992 to 0.995 , respectively. All RT-qPCRs were performed in duplicate. The recovery efficiency of each sample was calculated based upon the GC quantified by RT-qPCR: Recovery Efficiency $(\%)=($ Total viral RNA GC recovered/Total viral RNA GC seeded) $\times 100)($ Diez-Valcarce et al., 2012).

The concentration and viral extraction process performed adequately: $6 \pm 2 \%$ and $39 \pm 2 \%$ from sewage and river water, respectively. The significant difference of concentration rates can reflect both the effect of the type of water tested and the type of concentration protocol used. SARS-CoV-2 RNA was detected in sewage from the presidio and workers accommodation (average of $1.3 \times 10^{4}$ and $4.3 \times 10^{4}$ SARSCoV-2 GC mL ${ }^{-1}$ of sewage, respectively) (Fig. 2). Several epidemiological signs must be considered when analyzing the results, as cross-contamination between prison visitors and the area workers cannot be ruled out as social interactions between the prison visitors and workers were observed, and it is important to highlight that there is a considerable turnover of people in the workers accommodation. In this sense, the study serves as a non-invasive early warning for COVID-19 cases in areas with people agglomeration and population turnover associated to poor hygiene standards,

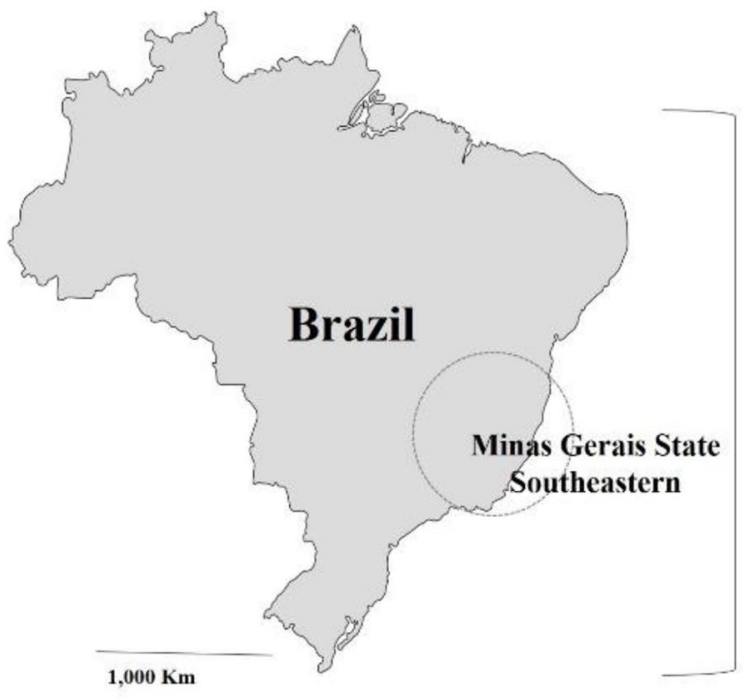

\section{Samples and sites}

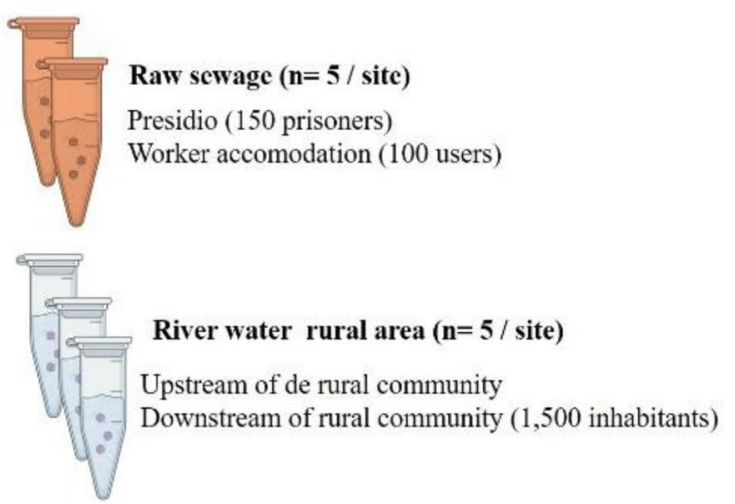

Fig. 1 Sampling and studied areas 


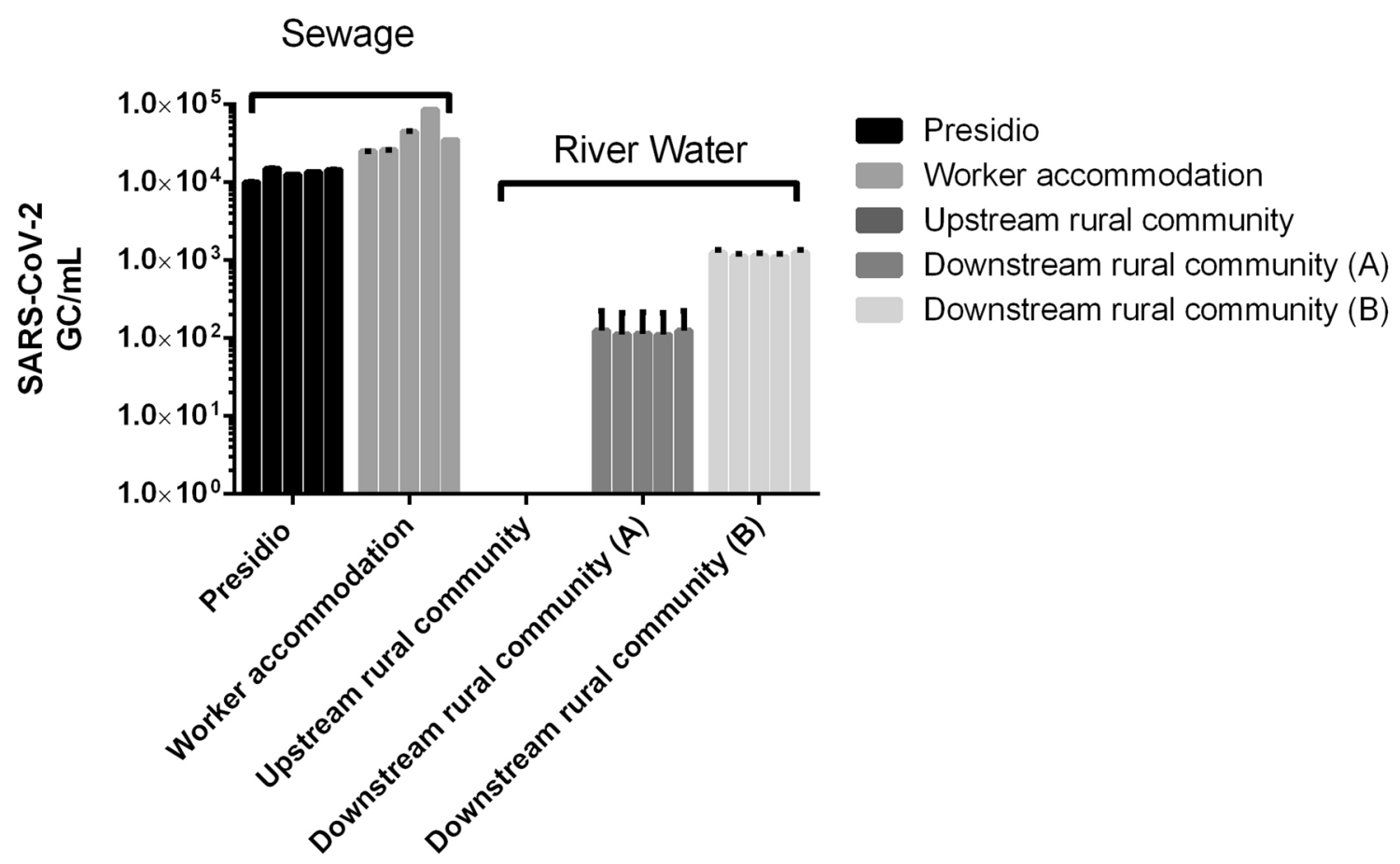

Fig. 2 Presence of SARS-CoV-2 RNA in river waters and human sewage from low sanitation and vulnerable areas in the Minas Gerais State region, Brazil in early August, 2020. The quantification of SARS-CoV-2 RNA is the average of the N1 and N2 copies by RT-qPCR

particularly in regions with insufficient sanitation system and neglected health systems (Lodder et al., 2020).

The sampling was performed on the same day for the upstream and downstream river water samples with a distance between the sampling sites of $6 \mathrm{~km}$. While SARS$\mathrm{CoV}-2$ was not detected in upstream river water from the rural community, SARS-CoV-2 was found in the two downstream river water sites (average of $1.1 \times 10^{2}$ and $1.7 \times 10^{3}$ SARS-CoV-2 GC mL ${ }^{-1}$ of water, respectively (Fig. 2). In the rural area assessed, basic sanitation systems are not available, with human sewage released directly in river waters. It was evident that the contamination of the rivers by SARS$\mathrm{CoV}-2$ indicates the poor sanitation of the region, especially in the downstream area of the rural community. Our results are in accordance with others with similar sanitation conditions, for example from urban streams of Quito, Ecuador (Guerrero-Latorre et al., 2020).

A very relevant epidemiological information is that the sampling areas where we carried out the studies had not registered official cases of COVID-19 at the time of the sampling (early August, 2020, more than 1 week prior to the first notification, 29th August, 2020). Studies have shown that increases in SARS-CoV-2 RNA can be detected in environmental samples several days prior to the appearance of confirmed COVID-19 cases (Peccia et al., 2020; Wurtzer et al., 2020). The aim of this study was not to evaluate the infectivity of SARS-CoV-2 in water and sewage, but there is important to investigate the potential risk of infections associated with the possible viral environmental route, mainly of more virulent strains (Lodder et al., 2020). Similarly, our findings suggest that there is either under diagnostics of active cases or intermittent SARS-CoV-2 excretion in patients who were asymptomatic. Another hypothesis raised is the possibility of delayed syndromic surveillance in Brazil, particularly problematic in remote areas. On the other hand, the results reinforce the potential of the environmental surveillance for non-invasive early warning, particularly of clusters or outbreaks in countries that have already controlled the transmission and are facilitating public health and social measures, or in the event of seasonality. In this context, the presence of SARS-CoV-2 RNA on sewage and river waters from low sanitation rural areas corroborates with the WHO recommendations for the use of environmental surveillance as a monitoring tool, complementing the clinical surveillance on areas with restricted and difficult access (WHO, 2020). This environmental monitoring strategy can be especially important in remote areas, with marginalized populations with poor hygiene standards, low or inexistent sanitation systems, informal settlements and extremely low-resource communities.

Acknowledgements D.S.M.S. received a Postdoc fellowship form the Federal Government of Brazil (CAPES/PNPD No 
88887.473179/2020-00). The authors thank Bio RENDER application for the support to draw the graphical abstract.

Data Availability All SARS-CoV-2 RT-qPCR data are available from the corresponding on reasonable request.

\section{Declarations}

Conflict of interest The authors declare that they have no known competing financial interests or personal relationships that could have appeared to influence the work reported in this paper.

\section{References}

Ahmed, W., Angel, N., Edson, J., Bibby, K., Bivins, A., O’Brien, J. W., et al. (2020). First confirmed detection of SARS-CoV-2 in untreated wastewater in Australia: A proof of concept for the wastewater surveillance of COVID-19 in the community. Science of the Total Environment, 728, 138764.

Ahmed, W., Harwood, V. J., Gyawali, P., Sidhu, J. P. S., \& Toze, S. (2015). Comparison of concentration methods for quantitative detection of sewage-associated viral markers in environmental waters. Applied and Environment Microbiology, 81, 2042-2049.

Besselsen, D. G., Wagner, A. M., \& Loganbill, J. K. (2003). Detection of lymphocytic choriomeningitis virus by use of fluorogenic nuclease reverse transcriptase-polymerase chain reaction analysis. Comparative Medicine, 53, 65-69.

CDC. (2020). Real-Time RT-PCR diagnostic panel for emergency use only. Cdc Eua, 3, 1-42.

Diez-Valcarce, M., Cook, N., Hernández, M., \& Rodríguez-Lázaro, D. (2012). Analytical application of a sample process control in detection of foodborne viruses. Food Analytical Methods, 4, 614-618.

Guerrero-Latorre, L., Ballesteros, I., Villacrés-Granda, I., Granda, M. G., Freire-Paspuel, B., \& Ríos-Touma, B. (2020). SARS-CoV-2 in river water: implications in low sanitation countries. Science of the Total Environment, 743, 140832.

La Rosa, G., Iaconelli, M., Mancini, P., Bonanno Ferraro, G., Veneri, C., \& Bonadonna, L. (2020). First detection of SARS-CoV-2 in untreated wastewaters in Italy. Sci. Total Environ., 736, 139652.
Lewis, G. D., \& Metcalf, T. G. (1988). Polyethylene glycol precipitation for recovery of pathogenic viruses, including hepatitis A virus and human rotavirus, from oyster, water, and sediment samples. Applied and Environment Microbiology, 54, 1983-1988.

Lodder, W., de Roda, Maria, \& Husman, A. (2020). SARS-CoV-2 in wastewater: potential health risk, but also data source. Lancet Gastroenterology \& Hepatology, 5, 533-534.

Medema, G., Heijnen, L., Elsinga, G., Italiaander, R., \& Brouwer, A. (2020). Presence of SARS-Coronavirus-2 RNA in sewage and correlation with reported COVID-19 prevalence in the early stage of the epidemic in The Netherlands. Environmental Science \& Technology Letters, 7, 511-516.

Peccia, J., Zulli, A., Brackney, D., Grubaugh, N., Kaplan, E., Casanovas-Massana, A., et al. (2020). SARS-CoV-2 RNA concentrations in primary municipal sewage sludge as a leading indicator of COVID-19 outbreak dynamics. medRxiv. https://doi.org/10.1101/ 2020.05.19.20105999.

Prado, T., Fumian, T. M., Mannarino, C. F., Maranhão, A. G., Siqueira, M. M., \& Miagostovich, M. P. (2020). Preliminary results of SARS-CoV-2 detection in sewerage system in niterói municipality, Rio de Janeiro, Brazil. Memórias do Instituto Oswaldo Cruz, $115,1-3$.

WHO. (2020). Status of environmental surveillance for SARS-CoV-2 virus. Scientific brief, pp. 1-4.

Wu, F., Xiao, A., Zhang, J., Moniz, K., Endo, N., \& Armas, F. (2020). SARS-CoV-2 titers in wastewater foreshadow dynamics and clinical presentation of new COVID-19 cases. medRxiv. https://doi. org/10.1101/2020.06.15.20117747.

Wurtzer, S., Marechal, V., Mouchel, J. M., Maday, Y., Teyssou, R., Richard, E., et al. (2020). Evaluation of lockdown effect on SARS$\mathrm{CoV}-2$ dynamics through viral genome quantification in waste water, Greater Paris, France, 5 March to 23 April 2020. Eurosurveillance Weekly, 25, 2000776.

Publisher's Note Springer Nature remains neutral with regard to jurisdictional claims in published maps and institutional affiliations. 